\title{
PEMETAAN PERILAKU BERISIKO GAY BERBASIS SNA SEBAGAI EARLY WARNING SYSTEM KASUS HIV/AIDS DI KOTA KENDARI
}

\author{
Jumartin Gerung \\ STIKES Mandala Waluya Kendari \\ jumartin.gerung@gmail.com
}

\begin{abstract}
Abstrak
Pada kasus HIV dalam skala nasional, menunjukkan bahwa kelompok heteroseks juga termasuk sebagai kelompok utama yang paling berisiko menderita HIV/AIDS. Peningkatan ini mencolok terjadi sejak 2015 angkanya masih di 4.241 kasus, dan meningkat hingga lebih dari dua kali lipat pada 2016 yang mencapai 13.063 kasus. Data pemetaan interaksi di sosial media khususnya wilayah Kendari terdapat sekitar 800 akun yang memberi interaksi perihal Gay. Hal ini diindikasikan akan mempengaruhi prevalensi kejadian HIV/AIDS di Kota Kendari. Penelitian ini bertujuan untuk memetakan interaksi perilaku berisiko Gay sebagai early warning system kasus HIV/AIDS. Social Network Analysis merupakan studi yang mempelajari tentang hubungan manusia dengan memanfaatkan teori graf. Penerapan Social NetworkAnalysis dalam suatu aplikasi mampu menggambarkan relasi atau hubungan antar individu dengan melakukan visualisasi terkait centrality (titik pusat), between centrality (jalur pendek), juga closeness centrality yakni rata-rata jalur terpendek dari interaksi akun di laman FB. Untuk platform Facebook berdasarkan pada hasil penghitungan diketahui bahwa akun yang berpengaruh terhadap interaksi jejaring sosial adalah akun Gay Kendari yang unggul pada nilai degree centrality,betweeness centrality, dan Closeness centrality. Akun Gay Kendari paling berpengaruh dalam interaksi jaringan sosial Facebook. Melalui social network analysis, penelitian ini memberikan gambaran relasi perilaku berisiko LSL/Gay sebagai early warning system kasus HIV/AIDS di kota kendari
\end{abstract}

Kata kunci: analisis jaringan sosiai, gay, sistem peringatan dini, HIV/AIDS

\begin{abstract}
In the case of HIV on a national scale, it shows that heterosexual groups are also included as the main groups most at risk of suffering from HIV / AIDS. This increase is striking since 2015 the figure is still at 4,241 cases, and has more than doubled in 2016 reaching 13,063 cases. Data mapping interaction on social media, especially in the Kendari region, there are about 800 accounts that provide interaction about Gay. This is indicated to affect the prevalence of HIV / AIDS in Kendari City. This study aims to map the interaction of gay risk behavior as an early warning system for HIV / AIDS cases. Social Network Analysis is a study that studies human relations by utilizing graph theory. The application of Social Network Analysis in an application is able to describe relationships or relationships between individuals by visualizing related to centrality (center point), between centrality (short path), also closeness centrality ie the average shortest path of account interactions on the FB page. For the Facebook platform based on the calculation results, it is known that the account that influences social networking interactions is the Gay Kendari account that excels at the value of degree centrality, betweenness centrality, and Closeness centrality. Kendari Gay Account is the most influential in Facebook social network interactions. Through social network analysis, this study provides an overview of the relationship of MSM / Gay risk behavior as an early warning system for HIV / AIDS cases in the city of Kendari
\end{abstract}

Keywords: Social network analysis, gay, early warning system, HIV / AIDS. 


\section{PENDAHULUAN}

Social Network Analysis merupakan studi yang mempelajari tentang hubungan manusia dengan memanfaatkan teori graf. Melihat permasalahan di atas, penerapan Social Network Analysis dalam suatu aplikasi yang mampu menggambarkan relasi atau hubungan antar individu dengan melakukan visualisasi dalam bentuk graf kiranya dapat membantu proses pemecahan masalah yang ada. Selain itu, akan dilakukan proses kalkulasi terhadap setiap relasi antar individu untuk menemukan centrality dari sebuah jejaring sosial yang didasarkan pada posisi masingmasing individu yang terkait dalam struktur jaringan. Dengan aplikasi ini, tiap individu dapat menganalisa jaringan sosial yang telah mereka bangun dan mengetahui centrality dari struktur jalinan relasi yang dimiliki oleh masing-masing individu ${ }^{(1)}$.

Pada social network, individu atau orang digambarkan sebagai nodes atau titik, sedangkan relasi yang terjadi antar individu disebut dengan edges atau links. Pada dasarnya sebuah jaringan sosial adalah sebuah peta yang terdiri atas banyak orang dimana di dalamnya terdapat relasi antar individunya. Di seluruh Indonesia, sesuai data Kemenkes tahun 2012, ada 1,095,970 pria yang hidup dengan perilaku seks sesama pria (LSL atau Lelaki Seks dengan Lelaki). Ini angka lima tahun yang lalu. Hampir pasti sudah bertambah ratusan ribu lagi. Perkiraan lain menyebutkan jumlah kaum gay setidaknya tiga persen dari total populasi Indonesia atau sekitar 7,000,000 orang.

Diketahui juga bahwa ada 14.608 orang yang meninggal akibat kasus HIV-AIDS itu. Untuk kasus AIDS sendiri, jumlah penderita laki-laki kurang lebih dua kali lipat dari penderita perempuan. Data kumulatif (19872016) menunjukkan bahwa kasus AIDS pada laki-laki berjumlah 48.977 orang, sementara 27.458 lainnya adalah kasus pada perempuan.

Bila dilihat berdasarkan kasus baru, tren HIV cenderung masih naik dalam kurun waktu 10 tahun terakhir. Angka kasus baru HIV pada 2006 tercatat ada 7.195 dan terus mengalami kenaikan tiga sampai empat kali lipat dalam beberapa tahun sesudahnya. Pada 2013, angka kasus baru HIV tercatat berjumlah 29.037 dan mencapai 41.250 pada 2016.

Sementara itu, dari kelompok risiko LSL (lelaki suka lelaki) terlihat adanya peningkatan dua kali lipat pada periode 2015-2016. Pada 2014, tercatat ada 391 ada kasus baru. Jumlah ini meningkat menjadi 510 kasus pada 2015. Bahkan, di 2016, jumlah kasus baru AIDS yang disebabkan oleh LSL mencapai 1.180 kasus. Senada dengan AIDS, pada kasus HIV, kelompok heteroseks juga menjadi kelompok utama yang paling riskan. Angkanya masih besar, pada 2016 tercatat ada 17.754 kasus. Angka belasan ribu tersebut tercatat mulai terjadi pada 2011 dengan jumlah 10.668 kasus. Peningkatan yang mencolok terjadi pada kelompok LSL pada periode 2015-2016. Pada 2015 angkanya masih di 4.241 kasus, dan meningkat hingga lebih dari dua kali lipat pada 2016 yang mencapai 13.063 kasus ${ }^{(2)}$.

Kota Kendari mencatatkan diri sebagai daerah terbanyak pengidap human immunodeficiency virus (HIV) di Sulawesi Tenggara (Sultra). Data Dinas Kesehatan (dinkes) Sultra menunjukkan bahwa Seluruh kabupaten dan kota di Sultra sendiri sudah ada kasus HIV. Tapi, yang terbanyak saat ini di Kota Kendari, sebanyak 257 kasus. Itu berdasarkan data yang diperoleh pada 2017 lalu. Jumlah kasus virus yang mematikan ini terus meningkat setiap tahunnya. Secara keseluruhan, selama 2017 Dinkes Sultra menemukan sebanyak 861 kasus HIV. Dari data tersebut masih ada yang belum ditemukan, yaitu mereka yang tidak pernah datang atau konseling kepada dinkes setempat. Kota Kendari menjadi kota terbesar kasus HIV, disebabkan oleh status kota ini sebagai ibu kota provinsi, yang mana tempat hiburan malam (THM) menjamur ${ }^{(3)}$.

Berdasarkan observasi lapangan, perilaku seks yang menyimpang saat ini banyak terjadi. Misal, LGBT (lesbian, gay, biseksual, dan transgender/transeksual) di kehidupan malam di Kota Kendari semakin nampak.

\section{METODE}

Penelitian ini menggunakan pendekatan social network analysis, dimana visualisasi jaringan dimodelkan dengan menggunakan metode graph tipe undirected. Kemudian dilakukan penghitungan nilai atribut jaringan yang terdiri penghitungan nilai centrality, closeness centrality, betweeness centrality untuk mengidentifikasi akun yang berpengaruh atau memilki nilai interaksi yang tinggi di dalam jaringan.

Data yang digunakan dalam penelitian ini merupakan data sekunder yang berupa seluruh unggahan user di dalam platform yang memuat konten Gay dengan keyword dan atau hashtag dan minimal memiliki satu interaksi dengan user lain seperti like, coment,share dan mention). Pengambilan data pada platform Facebook diambil dengan menggunakan teknik data scrapping menggunakan scrapper extention pada peramban Facebook. Konsep SNA yang digunakan untuk memetakan perilaku berisiko Gay dalam penelitian ini dengan melihat nilai centrality, betweenness, dan closeness ${ }^{(4)}$.

Nilai centrality tertinggi mewakili individu yang menjadi pusat komunikasi. Nilai betweenness mewakili individu yang menjadi penghubung antar individu yang lain. Nilai closeness mewakili kedekatan seorang individu dengan individu yang lain. Untuk mengetahui hal ini maka dilakukan penelitian untuk mengidentifikasi dan menganalisis berbagai pola komunikasi yang terjadi di Facebook

Penelitian dilakukan pada laman sosial media 
facebook dengan mapping daerah wilayah Kota Kendari. Adapun Waktu pelaksanaan penelitian yaitu kurang lebih sebulan dan dilaksanakan pada tahun 2019.

Populasi dalam penelitian ini adalah seluruh akun yang berada dalam cakupan link facebook yang di akses melalui sistem pencarian link yang saling terhubung baik lewat like, share maupun comment. Akun-akun ini selanjutnya dipetakan sebagai sampel untuk selanjutnya di susun dalam sociogram berdasarkan nilai centrality, nilai betweennes, nilai closeness dan nilai density.

Tahapan pengumpulan data dilakukan melalui beberapa tahap. Tahapan penelitian yang dilakukan dalam penelitian ini dijelaskan sebagai berikut.

1) Known User: Tahap ini adalah tahap menentukan objek penelitian. Objek penelitian adalah interaksi yang dilakukan oleh akun-akun pengguna situs jejaring sosial Facebook

yang berinteraksi dalam konteks perilaku berisiko Gay/LSL.

2) Penentuan node/titik masing-masing akun yang didasarkan atas jumlah like, comment and share.

3) Software Data Extraction : Dalam tahap ini dilakukan proses ekstraksi atau pengumpulan data dengan menggunakan metode data scrapping. Data yang diambil adalah data unggahan pengguna yang mengandung kata kunci Gay dan minimal memiliki satu buah interaksi yang terjadi antar dua aktor di dalam jaringan.

4) Pengolahan Data dan Measures Networks : Tahap ini merupakan tahap pengolahan data interaksi jaringan. Pola interaksi divisualisasikan dengan menggunakan metode graph dengan tipe undirected. Setelah visualisasi pola jaringan interaksi didapatkan selanjutkan dilakukan penghitungan nilai atribut jaringan yang menghitung delapan atribut yakni total nodes, total edges, average degree, average weighted degree, average path length, density, network diameter dan number of community.

Penghitungan Nilai Centrality : Pada tahap ini dilakukan penghitungan nilai centrality (degree centrality, closeness centrality, betweeness centrality dan eigenvector centrality) node atau akun untuk mengidentifikasi akun berpengaruh dengan jumlah interaksi yang tinggi.

\section{HASIL DAN PEMBAHASAN}

Untuk platform Facebook berdasarkan pada hasil penghitungan diketahui bahwa akun yang berpengaruh terhadap interaksi jejaring sosial adalah akun Gay Kendari1 yang unggul pada nilai degree centrality, betweeness centrality, dan eigenvector centrality.

Penelitian ini menggunakan pendekatan social network analysis, dimana visualisasi jaringan dimodelkan dengan menggunakan metode graph tipe undirected. Kemudian dilakukan penghitungan nilai centrality yang terdiri dari degree centrality, closeness centrality, betweeness centrality untuk mengidentifikasi aktor yang berpengaruh atau memilki nilai interaksi yang tinggi di dalam jaringan.

Data yang digunakan dalam penelitian ini merupakan data sekunder yang berupa seluruh unggahan user dimdalam platform yang memuat konten penyebaran country branding dengan keyword Gay kendari. Data penelitian dikumpulkan selama kurang lebih tiga bulan dari Mei hingga agustus 2019. Dengan penghitungan node sebagai berikut :

a) Degree centrality menghitung jumlah interaksi yang dimiliki oleh sebuah node. Untuk menghitung. nilai degree centrality dari node ni dapat dilakukan dengan menggunakan rumus sebagai berikut : $\mathrm{CD}(\mathrm{n} i)=\mathrm{d}(\mathrm{n} i)$

Keterangan

$\mathrm{d}(\mathrm{ni})$ = banyaknya interaksi yang diiliki oleh node ni dengan node lain di dalam network.

b) Betwenness centrality menghitung seberapa sering sebuah node dilewati oleh node lain untuk menuju ke sebuah node tertentu di dalam jaringan. Nilai ini berfungsi untuk menentukan peran aktor yang menjadi jembatan penghubung interaksi di dalam network. Untuk menghitung nilai degree centrality dari sebuah node dapat dilakukan dengan menggunakan rumus sebagai berikut $\mathrm{CB}(\mathrm{ni})=\Sigma \mathrm{gj} k(\mathrm{ni}) / \mathrm{gj} k$

Keterangan

gjk (ni) = jumlah jalur terpendek dari node $\mathbf{j}$ ke node $k$ yang melewati node $i$. gjk = banyaknya jalur terpendek antara 2 buah node dalam network

c) Closeness centrality menghitung jarak ratarata antara suatu node dengan seluruh node lain di dalam jaringan atau dalam kata lain mengukur kedekatan sebuah node dengan node lain.cDalam sebuah jaringan dengan $g$ node, closeness centrality dari node $\mathrm{ni}$ adalah sebagai berikut:

$C C(\mathrm{ni})=[\mathrm{N}-1 / \Sigma \mathrm{d}(\mathrm{ni}, \mathrm{n} j)]$

Keterangan :

$\mathrm{N}=$ jumlah node di dalam jaringan

$d(n i, n j)=$ jumlah jalur terpendek yang

menghubungkan node ni dan nj

Pengolahan data dalam penelitian ini 
dilakukan dengan menggunakan software Gephi. Software Gephi adalah sebuah aplikasi yang bersifat open source untuk melakukan eksplorasi dan manipulasi jaringan. Sebuah modul jaringan yang akan dikembangkan dapat diolah dengan diimpor, dan divisualisasikan. Titik pada gambar yang disebut 'node' atau simpul merepresentasikan personal atau individu yang dihubungkan oleh garis yang membentuk 'vertex'. Dua node yang terhubung dinyatakan dengan adanya garis yang menghubungkan keduanya. Visualisasi interaksi node dalam platform FB dapat dilihat pada gambar 1 berikut :

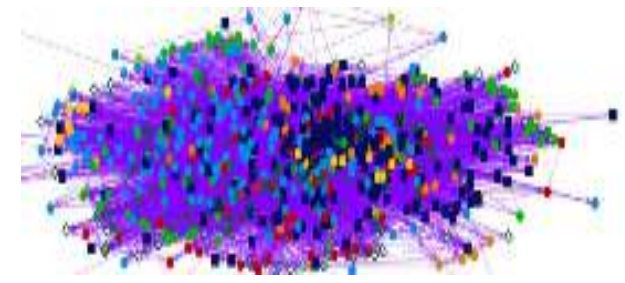

Data pada penelitian ini diperoleh dari media sosial facebook melalui komunitas/grup yang dibentuk oleh pengguna kurang lebih 20 group dengan sebaran akun yang saling berhubungan kurang lebih 5096 akun. Ini didasarkan pada beberapa akun pribadi yang saling berinteraksi melalui tombol like dan komentar.

Terdapat 20 akun dengan inisial yang sama yakni Gay Kendari, sehingga diberi tanda berupa angka dibelakang akun. Akun Gay Kendari1 menjadi akun paling berpengaruh dalam interaksi jaringan sosial Facebook dari total jumlah interaksi yang dihasilkan, kemudian menjadi penghubung atau jembatan bagi interaksi akun lain di dalam jaringan, memiliki kedekatan dengan akun lain yang ada disekitarnya sehingga membuat penyampaian informasi lebih cepat dan unggul dalam hubungan-nya terhadap akun berpengaruh lain di dalam jaringan.

Aplikasi komputasi berkembang searah dengan komputasi personal yang memfasilitasi pengguna untuk kolaborasi dan mengembangkan interaksi sosial. Fenomena ini dikenal sebagai 'social computing' ,bagian dari teknologi informasi yang mengupas irisan antara manusia dan studi sosial yang terhubung melalui jaringan komputer. Jaringan komputer pada akhirnya juga merupakan jaringan sosial yang menghubungkan manusia, organisasi dan pengetahuan. Disamping teknologi web sendiri telah memberikan keleluasaan pengguna untuk terikat dalam interaksi social dengan memberikan kontribusi keahliannya, berbagi konten dan menyebarluaskan informasi .

Hadirnya jejaring media sosial semakin menjembatani seseorang untuk memiliki banyak keterhubungan, baik secara offline maupun online. Fasilitas untuk berkolaborasi dan berinteraksi sosial sangat digemari saat ini, yang dibuktikan dengan semakin membengkaknya angka pengguna media jejaring sosial, seperti facebook, twitter, flikr dan sebagainya ${ }^{(5)}$.

Berkomunitas adalah salah satu solusi ketika seseorang merasa awam dengan hal baru yang dimilikinya dan ingin menggali lebih banyak informasi mengenainya. Tentu saja komunitas yang dimaksud di sini adalah sekumpulan pengguna komputer yang secara eksplisist mendefinisikan dirinya dalam suatu platform, misalnya Flikr, Tweeter atau Facebook, yang memberikan dukungan informasi pada lingkungannya tersebut, termasuk dalam tukar menukar informasi dan bahkan aktivitas bersama secara offline.

Penelitian mengenai SNA (Social Network Analysis) sebenarnya sudah dimulai puluhan tahun yang lalu, jauh sebelum era media sosial seperti Facebook dan Twitter. Analisa jejaring sosial merupakan suatu teknik untuk memetakan dan mengukur relasi dan komunikasi yang terjadi antar manusia, kelompok, organisasi, komputer ataupun entitas yang memproses suatu informasi. Hubungan relasi ini divisualisasikan dengan graph SNA (selanjutnya disebut sociogram) yang tervisualisasi sehingga menjadi lebih mudah untuk dianalisis. Hubungan relasi ini divisualisasikan dengan graph seperti yang terlihat pada gambar 1 . Titik pada gambar yang disebut 'node' atau simpul merepresentasikan personal atau individu yang dihubungkan oleh garis yang membentuk 'vertex'. Dua node yang terhubung dinyatakan dengan adanya garis yang menghubungkan keduanya ${ }^{(6)}$.

Data pada penelitian ini diperoleh dari media sosial facebook melalui komunitas/grup Gay kendari yang dibentuk oleh pengguna dan didapatkan kurang lebih 20 grup dengan sebaran akun yang saling berhubungan kurang lebih 5096 akun. Ini didasarkan pada beberapa akun pribadi yang saling berinteraksi melalui tombol like dan komentar.

Untuk platform Facebook berdasarkan pada hasil penghitungan diketahui bahwa akun yang berpengaruh terhadap interaksi jejaring sosial adalah akun Gay Kendari1 yang unggul pada nilai degree centrality,betweeness centrality, dan eigenvector centrality.Terdapat 20 akun dengan inisial yang sama yakni Gay Kendari, sehingga diberi tanda berupa angka dibelakang akun. Lima akun dengan tingkat Interaksi tertinggi dapat dilihat pada tabel berikut : 


\begin{tabular}{|c|c|c|c|}
\hline Node & $\begin{array}{l}\text { Degree } \\
\text { Centrality }\end{array}$ & $\begin{array}{l}\text { Betweenees } \\
\text { Centrality }\end{array}$ & $\begin{array}{l}\text { Closeness } \\
\text { Centrality }\end{array}$ \\
\hline $\begin{array}{l}\text { Score / } \\
\text { (Rank) }\end{array}$ & $\begin{array}{l}\text { Score / } \\
\text { (Rank) }\end{array}$ & Score & $\begin{array}{l}\text { Score / } \\
\text { (Rank) }\end{array}$ \\
\hline $\begin{array}{l}\text { Gay } \\
\text { kendari1 }\end{array}$ & $3201 /(1)$ & $1600 /(1)$ & 1.0 \\
\hline $\begin{array}{l}\text { Gay } \\
\text { kendari2 }\end{array}$ & 615 / (2) & 729 / (2) & 1.0 \\
\hline $\begin{array}{l}\text { Gay } \\
\text { kendari3 }\end{array}$ & $264 /(3)$ & 662 / (3) & 1.0 \\
\hline $\begin{array}{l}\text { Gay } \\
\text { Kendari4 }\end{array}$ & $240 /(4)$ & $618 /(8)$ & 1.0 \\
\hline $\begin{array}{l}\text { Gay } \\
\text { Kendari5 }\end{array}$ & 129 / (5) & $401 /(11)$ & 1.0 \\
\hline
\end{tabular}

Akun Gay Kendari1 menjadi akun paling berpengaruh dalam interaksi jaringan sosial Facebook dari total jumlah interaksi yang dihasilkan, kemudian menjadi penghubung atau jembatan bagi interaksi akun lain di dalam jaringan, memiliki kedekatan dengan akun lain yang ada disekitarnya sehingga membuat penyampaian informasi lebih cepat dan unggul dalam hubungan-nya terhadap akun berpengaruh lain di dalam jaringan. Akun-akun pendukung lain yang juga memiliki pengaruh yang cukup besar dalam interaksi jejaring sosial Facebook adalah akun riyan saputra world, iksan Gay cocoe Kendari,Dhesta gay yang di share oleh akun Gay Kendari.

Pemetaan interaksi pada platform facebook menunjukkan adanya kenaikan signifikan dari komunitas Gay di Kota Kendari. Sebagai kelompok berisiko terkena HIV/AIDS tentu ini perlu perhatian. Sebagaimana diketahui, berdasarkan data nasional dari kelompok risiko LSL (lelaki seks lelaki) terlihat adanya peningkatan dua kali lipat pada periode 20152016. Pada 2014, tercatat ada 391 ada kasus baru. Jumlah ini meningkat menjadi 510 kasus pada 2015. Bahkan, di 2016, jumlah kasus baru AIDS yang disebabkan oleh LSL mencapai 1.180 kasus. Senada dengan AIDS, pada kasus HIV, kelompok heteroseks juga menjadi kelompok utama yang paling riskan.

Peningkatan kejadian HIV/AIDS secara nasional berpotensi di alami sulawesi tenggara khususnya Kota Kendari, melihat kian bertambahnya komunitas Gay di Kota ini.

\section{SIMPULAN DAN SARAN}

Mapping interaksi perilaku berisiko Gay di kota Kendari menunjukkan adanya akun yang tercakup dalam komunitas ini kurang lebih 20 grup dan interaksi akun mencapai angka 5000. Penerapan Social Network Analysis dalam aplikasi Gephi mampu menggambarkan relasi atau hubungan antar individu dengan melakukan visualisasi terkait centrality (titik pusat), between centrality (jalur pendek), juga closeness centrality yakni rata-rata jalur terpendek dari interaksi akun di laman FB. Hasil yang ditemukan ini dapat digunakan oleh pengambil kebijakan sebagai early warning system kasus HIV/AIDS di Kota Kendari.

\section{DAFTAR PUSTAKA}

1. Alamsyah, A., Putri, F., \& Sharif, O. O. 2013. Social Network Modelling Approach for Brand Awareness. The 5th IndonesianInternational Conference on Innovation, Entrepreneurship, and Small Business, p2-8.

2. Kemenkes RI. 2017. Statistik kasus HIV/AIDS di Indonesia. Jakarta: Direktorat Jenderal Pengendalian Penyakit dan Penyehatan Lingkungan Kementrian Kesehatan RI

3. Bastian, M., Heymann, S., \& Jacomy, M. 2009. Gephi: An Open Source Software for Exploring and Manipulating Networks. Proceedings of the Third International ICWSM Conference (pp. 12). ICWSM Conference.

4. Bohn, A., Feinerer, I., Hornik, K., dan Mair, P. 2011. Content-Based Social Network Analysis of Mailing Lists. The Journal, 11-18. The Computer Advisor. Web site scraper the most effective tool for web data extraction, Retrieved October 28, 2017 from http://www.thecomputeradvisor.net/web-sitescraper-the-most-effective-tool-for-web-dataextraction/.

5. Chau, D. H., Pandit, S., Wang, S., \& Faloutsos, C. 2007. Parallel crawling for online social networks. In Proceedings of the 16th international conference on World Wide Web (pp. 1283-1284). ACM.

6. Yuliana I, Grafika J, Yogyakarta N, Grafika J, Yogyakarta N. 2015. Analisis Jejaring Media Sosial untuk Pemetaan pada Komunitas Online. Hal 14-17

7. Juditha C. 2017. Memahami Struktur Jaringan Media Sosial sebagai Cara Strategis Periklanan di Era Ekonomi Digital Understanding Social Media Network Structure as a Strategic Way of Advertising in Digital Economy Era. Vol. 2(1):99114

8. Oetomo D, Suvianita K, Halim KSS, Soeparna S, Surahman L. 2013. Hidup Sebagai LGBT di Asia: Laporan Nasional Indonesia (Tinjauan dan Analisa Partisipatif tentang Lingkungan Hukum dan Sosial bagi Orang dan Masyarakat Madani Lesbian, Gay, Biseksual, dan Transgender (LGBT). Lap LGBT Nas Indones.

9. Prasetyo R. Psychology of the Media : Scopes and Methods.

10. allis A. 2013. 済無No Title No Title. J Chem Inf 
$\begin{array}{lll}\text { Model. } & \text { Vol. 53(9):1689-1699. doi:10.1017/CBO9781107415324.004 }\end{array}$ 